\title{
Middle to late Holocene paleoproductivity reconstructions for the western Barents Sea: a model-data comparison
}

\author{
Irene Pathirana $^{1,2} \cdot$ Jochen Knies $^{1,3} \cdot$ Maarten Felix $^{4} \cdot$ Ute Mann $^{5}$ • \\ Ingrid Ellingsen ${ }^{6}$
}

Received: 24 August 2015/ Accepted: 13 October 2015/Published online: 30 November 2015

(c) The Author(s) 2015. This article is published with open access at Springerlink.com

\begin{abstract}
In this study we focus on late Holocene primary productivity (PP) variability in the western Barents Sea and its response to variable sea ice coverage by combining PP reconstructed from several sediment cores with regional PP trends simulated with a well-constrained organic facies model, OF-Mod 3D. We find that modern production rates reconstructed from buried marine organic matter ("bottomup") resemble simulated export production at $50 \mathrm{~m}$ water depth inferred from numerical simulations of surface water $\mathrm{PP}$ in a 3D ocean model, SINMOD ("top-down"). Paleoproductivity rates in the northern Barents Sea are more variable and generally higher $\left(30-150 \mathrm{gC} \mathrm{m}^{-2}\right.$ year $\left.^{-1}\right)$ than in the SW Barents Sea region $\left(<75 \mathrm{gC} \mathrm{m}^{-2}\right.$ year $\left.^{-1}\right)$ throughout the last 6000 years BP. In the SW Barents Sea, PP rates and terrestrial organic matter (TOM) supply remain constantly low indicating present-day-like oceanographic conditions
\end{abstract}

Jochen Knies

Jochen.Knies@ngu.no

Irene Pathirana

irene.pathirana@gmail.com

1 Geological Survey of Norway, 7491 Trondheim, Norway

2 Department of Geology, University of Troms $\varnothing, 9037$ Troms $\emptyset$, Norway

3 CAGE - Centre for Arctic Gas Hydrate, Environment and Climate; Department of Geology, University of Troms $\varnothing$, 9037 Troms $\varnothing$, Norway

4 Department of Geology and Mineral Resources Engineering, NTNU - Norwegian University of Science and Technology, 7491 Trondheim, Norway

5 Statoil Research Center, Arkitekt Ebbells veg 10, 7005 Trondheim, Norway

6 SINTEF Fisheries and Aquaculture, 7465 Trondheim, Norway with only marginal influence of sea ice related processes during the last 6000 years BP. PP rates in the northern Barents Sea indicate a shift from stable modern-like conditions prior to $2800 \mathrm{BP}$ to denser, more permanent sea ice coverage along the marginal ice zone (MIZ) between 2800 and 1000 years $\mathrm{BP}$ and low PP rates. PP rates increase around 1000 years BP indicating a northward shift of the MIZ and accelerated export towards the seabed. During the last 500 years a pronounced decline in PP rates towards the present day indicates reduced annual duration of the MIZ in the area due to global warming. Our results suggest that a combination of first-year ice and higher PP in a warming pan-Arctic may point to a potential Arctic carbon sink while sea ice is still present.

Keywords Primary productivity $\cdot$ Holocene $\cdot$ Barents Sea

\section{Introduction}

The recent decline in Arctic sea ice cover has been attributed to numerous factors including Arctic temperature rise, changes in atmospheric circulation patterns, and enhanced warm water advection (e.g. [7, 10, 54, 63], as well as combinations of these factors. The effect of shrinking sea ice and its associated feedbacks on both Arctic marine and terrestrial ecosystems are currently a matter of intense debate (e.g. [19, 42, 55, 56]. One aspect that remains poorly understood is the effect of climate change for pan-Arctic marine primary production, and different scenarios have been suggested.

Primary production refers to the generation of organic carbon through photosynthesis by algae in the upper water column and is generally light and nutrient limited (e.g. [50]. Total or gross primary production (GPP) can be divided into regenerated production and new production. 
New production is production based on allochthonous nutrients from outside the euphotic zone (e.g. from upwelling, admixture of nutrient-rich deep water, windinduced mixing). Phytoplankton blooms (e.g. along the ice edge in the marginal ice zone (MIZ) in spring) are new productions. Regenerated production is production sustained by recycled nutrients from within the euphotic zone. The flux of organic matter that sinks out of the euphotic zone and is potentially available for burial in the sediments is referred to as export production and is limited by the amount of new production. On timescales longer than 1 year new and export production are balanced (see e.g. $[49,50]$ and references therein). Primary production reconstructed from sedimentary parameters ("bottom-up") refers usually to total primary production at the sea surface. On the other hand, primary production from biological and oceanographic parameters ("top-down") is usually presented for the euphotic zone whose depth varies with season and follows the halocline/pycnocline (deep winter layer, shallow spring and summer layer).

The Barents Sea is regarded as one of the most productive Arctic shelf regions with annual mean production of $102 \mathrm{gC} \mathrm{m}^{-2}$ year $^{-1}$ [45]. There have been various efforts in the oceanography community to quantify and predict marine primary production in the Barents Sea and the Arctic Ocean through in situ measurements (e.g. [33, 46]), satellite data (e.g. [8]), ocean models (e.g. [72]) or a combination of these (e.g. [36] and references therein). In situ measurements report values between 38 and $538 \mathrm{gC} \mathrm{m}^{-2}$ year $^{-1}$ (103-1475 $\mathrm{mgC} \mathrm{m}^{-2} \mathrm{day}^{-1}$ [20], and references therein). Dalpapado et al. [8] determined new production (NPP) in the Barents Sea from satellite data and an ocean model and found the highest NPP in the Atlantic sector $\left(113 \mathrm{gC} \mathrm{m}^{-2}\right.$ year $\left.^{-1}\right)$, lowest NPP in the Arctic sector $\left(30 \mathrm{gC} \mathrm{m}^{-2}\right.$ year $\left.^{-1}\right)$ and intermediate NPP in the MIZ $\left(44 \mathrm{gC} \mathrm{m}^{-2}\right.$ year $\left.^{-1}\right)$.

Amongst the possible responses to global warming, numerous studies have suggested increased primary production in the Arctic (e.g. [2, 18, 69]. Longer ice-free periods during summer may allow more heating of the upper water masses, which, in turn, may increase stratification and suppress the upward mixing of nutrients into the photic zone. On the other hand, enhanced wind stress due to less sea ice fosters upwelling of nutrients and counterbalances the effect of increased stratification [19]. The interplay between sea ice thickness and duration with solar insolation and heat is responsible for the timing of ice algal and phytoplankton blooms [31]. Reduced sea ice leads to decreased albedo and additional heat input into the ocean [41]. This provides an increased area for algal growth and a longer growing season leading to increased production $[2,11]$. Earlier blooms are not limited by grazers and the potential for higher vertical flux to sediments is increased [22,37]. The overall effect of these counteracting processes is as of yet unclear. "Top- down" modelling of Barents Sea and pan-Arctic primary productivity in future climate scenarios suggests an overall increase of GPP in the Arctic regions due to decreasing ice coverage, more open water, and a northward shift of nutrients [11, 59]. Ellingsen et al. [11] found an $8 \%$ increase in average primary production (due to higher production in the northern Barents Sea) in a future projection for the period from 1995 to 2059 (IPCC B2 scenario) using the 3D ocean model SINMOD. Regionally, however, overall GPP in the SW Barents Sea Atlantic Water (AW) sector is projected to decrease [59], alluding to the importance of sea ice in the system. The MIZ region is characterized by first-year ice that forms in winter, collects sediment, and melts in spring leading to the well-known phytoplankton blooms and high productivity [51, 72].

To improve the understanding of the impact of shrinking Arctic sea ice on marine productivity, reconstruction of productivity during past periods of variable sea ice coverage is especially important. Paleoproductivity (PP) reconstruction for the last 100 years from organic carbon burial in Storfjorden, southern Spitsbergen, shows a negative correlation to shrinking sea ice and increasing air temperatures [76]. This suggests that less sea ice in the Barents Sea may not cause an increase in marine productivity contrary to what is suggested by Ellingsen et al. [11]. This negative PP trend is likely explained by a reduced annual duration of the marginal ice zone in the Storfjorden due to global warming. It has been shown that the proximity of the marginal ice zone (MIZ) and enhanced nutrient supply during sea ice melting sustain high productivity in surface waters [12, 45, 72].

In the present study we focus on late Holocene PP variability in the western Barents Sea and its response to variable sea ice coverage. We combine PP reconstructed from sediment core data and locally inferred temporal trends with regional PP trends used as input in a wellconstrained organic facies model, OF-Mod 3D. The regional PP distribution was determined so that simulated organic carbon in sediments matched measured core values. Our "bottom-up" approach is able to shed light on the importance of first-year ice in carbon production and drawdown to the sediments compared to an ice-free Arctic scenario. In addition we compare our simulated regional PP distribution to simulations of modern surface water productivity in the Barents Sea (SINMOD) and discuss discrepancies between the two modelling results in the light of the different modelling approaches.

\section{Physiogeographic setting}

Figure 1 gives an overview over the study region in the western Barents Sea, including the surface currents, ice extent, and locations of the sediment cores used in this 
Fig. 1 Map of the study area with surface circulation (red Atlantic Water (AW), blue Arctic Water (ArW)), Polar Front (after [32]), maximum winter ice extent for the past 250 years [40], modeled area (dash dot) and sample locations indicated

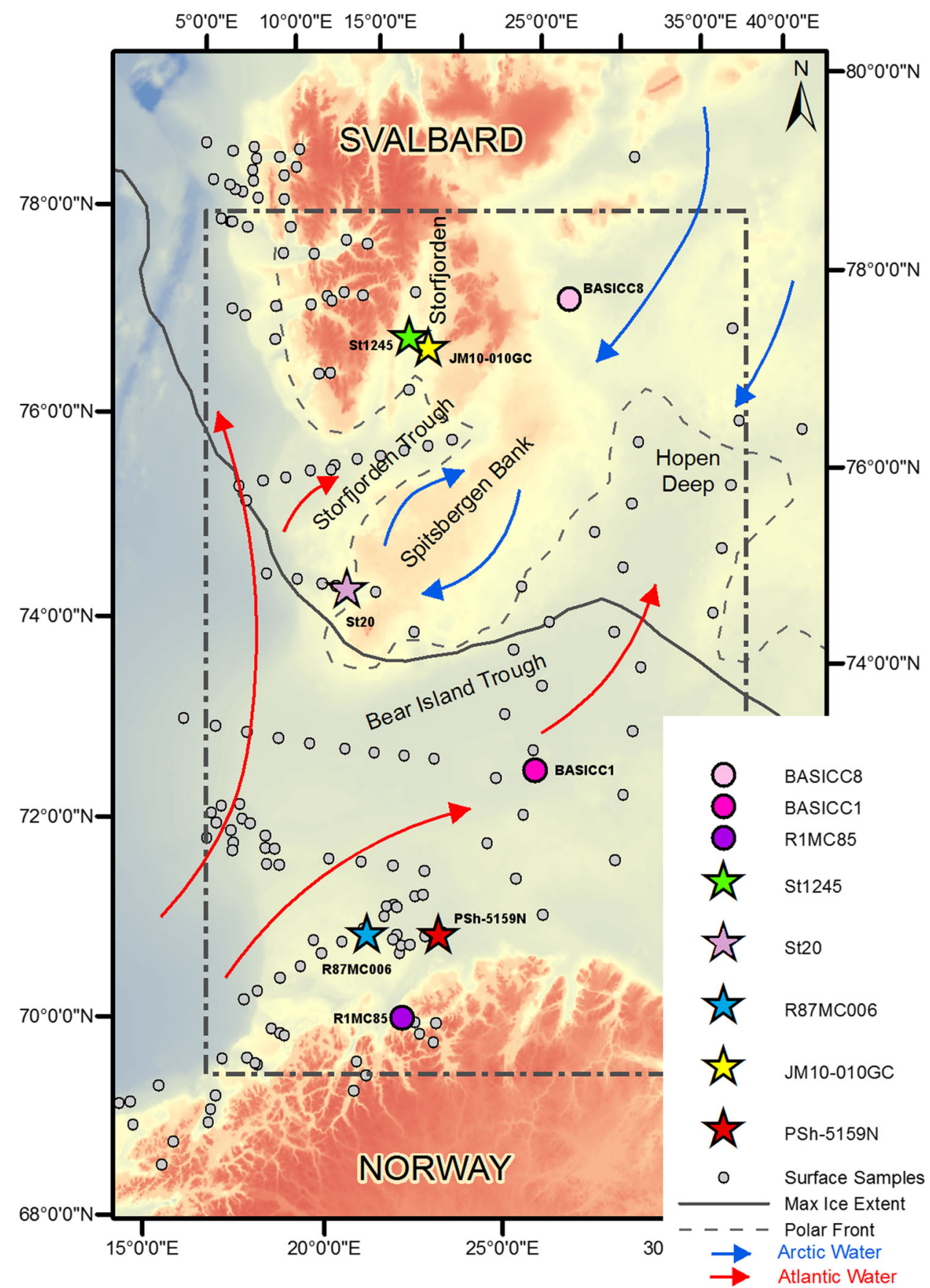

study. The study region includes Bear Island and Spitsbergen Bank, a shallow bank where water depth is $<30 \mathrm{~m}$ at its shallowest point. There are two deeper channels in this region, Bear Island Trough (ca. $500 \mathrm{~m}$ deep) south of Bear Island and Storfjorden Trough (ca. $250 \mathrm{~m}$ deep) south of Svalbard. The two main water masses are the warm, saline AW flowing into the Barents Sea from the southwest and the cold, fresh Arctic water (ArW) entering the Barents Sea from the northeast. The AW flows northward along the shelf and branches out eastward into Bear Island Trough while the ArW flows southwestward along the flanks of Spitsbergen Bank. A detailed description of the water masses and circulation regime can be found in Loeng [32]. The ArW from the northeast and the AW from the southwest are separated by the Polar Front (PF), a mainly topographically controlled density barrier that follows the $250 \mathrm{~m}$ isobaths [32]. The position of the PF also depends on the relative strengths of the two water masses. The 
Table 1 Overview over the core data used in this study (LSR = linear sedimentation rate in $\mathrm{cm} \mathrm{kyr}^{-1}$ )

\begin{tabular}{|c|c|c|c|c|c|c|c|c|c|c|}
\hline Core & References & $\begin{array}{l}\text { Lat. } \\
\mathrm{N}\end{array}$ & $\begin{array}{l}\text { Long. } \\
\text { E }\end{array}$ & Environment & $\begin{array}{l}\text { Water } \\
\text { depth } \\
\text { (m) }\end{array}$ & $\begin{array}{l}\text { Core } \\
\text { length } \\
(\mathrm{m})\end{array}$ & $\begin{array}{l}\text { Dating } \\
\text { method }\end{array}$ & $\begin{array}{l}\text { Number } \\
\text { of dating } \\
\text { points }\end{array}$ & $\begin{array}{l}\text { Average } \\
\text { LSR } \\
\left(\mathrm{cm} \mathrm{kyr}^{-1}\right)\end{array}$ & $\begin{array}{l}\text { Used } \\
\text { for } \\
\text { PP }\end{array}$ \\
\hline $\mathrm{R} 1 \mathrm{MC} 85$ & Jensen et al. [24] & 70.46 & 21.68 & $\begin{array}{l}\text { Fjord, Norwegian } \\
\text { coast, Atlantic and } \\
\text { Coastal Water }\end{array}$ & 466 & 0.22 & ${ }^{210} \mathrm{~Pb}$ & 1 & 210 & No \\
\hline \multirow[t]{2}{*}{ R87MC006 } & Pathirana et al. [40] & \multirow[t]{2}{*}{71.31} & \multirow[t]{2}{*}{20.32} & \multirow{2}{*}{$\begin{array}{l}\text { Open ocean, Atlantic } \\
\text { Water, ice free }\end{array}$} & \multirow[t]{2}{*}{240} & \multirow[t]{2}{*}{0.21} & ${ }^{14} \mathrm{C}$ & 1 & 4 & Yes \\
\hline & Jensen et al. [25] & & & & & & ${ }^{210} \mathrm{~Pb}$ & 1 & 80 & No \\
\hline BASICC1 & Vare et al. [68] & 73.10 & 25.63 & $\begin{array}{l}\text { Open ocean, Atlantic } \\
\text { Water, ice free }\end{array}$ & 425 & 0.37 & ${ }^{210} \mathrm{~Pb}$ & 18 & 108.99 & No \\
\hline BASICC8 & Vare et al. [68] & 77.98 & 26.80 & $\begin{array}{l}\text { Open ocean, Arctic } \\
\text { Water, seasonally } \\
\text { ice covered }\end{array}$ & 135 & 0.32 & ${ }^{210} \mathrm{~Pb}$ & 14 & 103.50 & No \\
\hline St20 & Pathirana et al. [40] & 74.82 & 18.02 & $\begin{array}{l}\text { Polar Front, ice } \\
\text { margin, Atlantic } \\
\text { Water/Arctic Water }\end{array}$ & 296 & 0.27 & ${ }^{14} \mathrm{C}$ & 2 & 63 & Yes \\
\hline St1245 & $\begin{array}{l}\text { Winkelmann and } \\
\text { Knies [76] }\end{array}$ & 77.50 & 19.13 & $\begin{array}{l}\text { Fjord, Arctic Water, } \\
\text { seasonally ice } \\
\text { covered }\end{array}$ & 180 & 0.29 & $\begin{array}{l}{ }^{14} \mathrm{C} \\
\text { and } \\
{ }^{137} \mathrm{Cs}\end{array}$ & 4 & 186.95 & Yes \\
\hline PSh-5159N & $\begin{array}{l}\text { Risebrobakken et al. } \\
\text { [48] }\end{array}$ & 71.37 & 22.65 & $\begin{array}{l}\text { Open ocean, Atlantic } \\
\text { Water }\end{array}$ & 422 & 2.9 & ${ }^{14} \mathrm{C}$ & 11 & 44.85 & Yes \\
\hline $\begin{array}{l}\text { JM10-10GC } \\
\text { (JM10) }\end{array}$ & $\begin{array}{l}\text { Rasmussen and } \\
\text { Thomsen }[43,44] \\
\text { for age model. }\end{array}$ & 77.41 & 20.10 & $\begin{array}{l}\text { Fjord, Arctic Water, } \\
\text { seasonally ice- } \\
\text { covered }\end{array}$ & 123 & 4.02 & ${ }^{14} \mathrm{C}$ & 9 & 55 & Yes \\
\hline & $\begin{array}{l}\text { This study for } \\
\text { organic } \\
\text { geochemical data }\end{array}$ & & & & & & & & & \\
\hline
\end{tabular}

northern part of the study region is partially covered by sea ice in the winter. Melting of the ice in spring and summer together with increased insolation and heat leads to a stratified water column in this marginal ice zone (MIZ) that induces a phytoplankton bloom that follows the receding ice edge northward [51].

Figure 1 and all following maps also show the maximum southernmost ice extent in the western Barents Sea over the last 250 years to distinguish between the ice-influenced northern and ice-free southern part of the study region. The ice edge is defined as the outer boundary for $30 \%$ ice concentration based on Divine and Dick [9] (see [40], for details).

\section{Materials and methods}

This study is based on the investigation of 2 gravity cores and 5 multicore segments retrieved during various marine research cruises in the Barents Sea between 2003 and 2010. The cores were sub-sectioned and samples were frozen at $-20{ }^{\circ} \mathrm{C}$ until freeze-drying prior to analyses. The current investigations are supplemented by published results from
Winkelmann and Knies [76] (multicore St1245) and Risebrobakken et al. [48] (gravity core PSh-5159N). Core JM10-10GC is referred to as JM10 in text and figures and core R87MC006 as R87. Table 1 gives an overview over the core locations, environments, dating methods, sedimentation rates and main references for these cores.

\section{Elemental analysis}

Total organic carbon (TOC in weight percent, wt\%) was determined using a LECO CS 244 analyzer. Aliquots (200 mg or $500 \mathrm{mg}$ ) of the samples were treated with $10 \%$ (volume) hydrochloric acid $(\mathrm{HCl})$ at $60{ }^{\circ} \mathrm{C}$ to remove carbonate and washed with distilled water to remove excess $\mathrm{HCl}$. Possible loss of organic material due to acid leaching is not taken into account. For core JM10, 23 samples were measured in duplicate yielding a standard deviation of 0.015 and $0.89 \%$ relative error.

Stable isotope ratios of the organic carbon fraction $\left(\delta^{13} \mathrm{C}_{\mathrm{org}}\right)$ and the nitrogen fractions were determined by elemental analyzer isotope ratio mass spectrometry (EAIRMS) on a Europa Scientific RoboPrep-CN elemental analyzer by Iso-Analytical, Crewe, UK, following the 
procedure described in Knies et al. [27]. Values of $\delta^{13} \mathrm{C}_{\mathrm{org}}$ were determined on decarbonated samples. Total nitrogen was determined on aliquots of freeze-dried, homogenized samples, while inorganic nitrogen was determined on $\mathrm{KOBr}-\mathrm{KOH}$ treated aliquots following Silva and Bremner [57]. Twenty percent of the samples were measured in duplicate with a standard deviation of 0.03 and a coefficient of variance of $1.68 \%$. Organic nitrogen was calculated as the difference between total nitrogen and inorganic nitrogen.

\section{Organic matter sources}

Marine organic carbon (MOC) and terrestrial organic matter (TOM) were distinguished in Barents Sea sediments using a mixing model based on total organic carbon (TOC), nitrogen content, and stable isotopes of organic matter $\left(\delta^{13} \mathrm{C}_{\text {org }}\right)[29,40,76]$ to define the endmembers of the mixing model. For the purposes of this paper, the set of Barents Sea surface samples of Knies and Martinez [29] is used as the calibration data set and the endmembers determined therein are used here. The terrestrial $\delta^{13} \mathrm{C}_{\mathrm{org}}$ endmember is calculated from a linear regression analysis of $\delta^{13} \mathrm{C}_{\text {org }}$ versus $\mathrm{N}_{\text {org }}$ /TOC giving a value of $-26.1 \%$, which is within a window of known endmembers for terrestrial organic matter in the Arctic (e.g. [64], and references therein). Knies and Martinez [29] showed that the marine nitrogen endmember is represented by its organic fraction, i.e. $\% \mathrm{~N}_{\mathrm{org}}$ (of total) $=100 \%$, and a linear regression analysis of $\% \mathrm{~N}_{\text {org }}$ and $\delta^{13} \mathrm{C}_{\text {org }}$ gives a marine $\delta^{13} \mathrm{C}_{\text {org }}$ endmember of $-20.1 \%$ at $100 \% \mathrm{~N}_{\text {org }}[29,40]$. We interpret these endmembers (from the surface sample data set) as representative for the Barents Sea and use them to calculate the terrestrial (TOM) and marine (MOC) organic carbon fractions and to calibrate the organic facies model.

\section{Primary productivity reconstruction}

Marine primary productivity ( $\mathrm{PP}$ in $\mathrm{gC} \mathrm{m}^{-2}$ year $^{-1}$ ) for the sediment cores is reconstructed based on the amount of marine organic carbon only (MOC in wt\%, determined as described above), dry bulk density (DBD in $\mathrm{g} \mathrm{cm}^{-3}$ ), linear sedimentation rate (LSR in $\mathrm{cm} \mathrm{kyr}^{-1}$ ) and water depth ( $\mathrm{z}$ in $\mathrm{m})$. To calculate PP the following equation was used ([28], and references therein):

$\mathrm{PP}=\left(\frac{\mathrm{MOC} * 0.378 * \mathrm{DBD} * \mathrm{LSR} * z^{0.63}}{\left(1-\left(\frac{1}{0.037 * \mathrm{LSR}^{1.5}+1}\right)\right)}\right)^{0.71}$

The PP equation (Eq. 1) used here on the core data accounts for carbon flux through the water column and processes affecting burial in the sediments (see $[28,35,40]$ for details on the equations).

\section{OF-Mod 3D model set-up}

OF-Mod 3D (Organic Facies Model 3D) simulates the deposition and burial of organic carbon on a basin scale, and is based on the interaction between inorganic and organic basin fill, as well as preservation of organic material [35]. Pathirana et al. [40] calibrated the OF-Mod 3D model in the Barents Sea by applying the organic matter properties of a set of surface sediment samples. The model was shown to be well-suited to investigate the regional distribution of the organic carbon fractions (marine and terrigenous) beyond core control. The inorganic basin fill is modelled based on the present-day bathymetric depth and Holocene thickness maps (see [40], for details). In OF-Mod 3D, the organic carbon is split into three different fractions: autochthonous marine (MOC), allochthonous (higher plant-based) terrigenous (C-TERR), and residual (soil/highly degraded) organic carbon [35].

The model grid consists of $125 \times 200$ square cells (cell size $5000 \mathrm{~m}$ ) and 15 vertical layers between $0 \mathrm{kyr}$ (top layer) and $10 \mathrm{kyr}$ (bottom layer) between Norway and Svalbard. In OF-Mod 3D, primary productivity (PP) is an input function and is defined such that the surface sample data set is reproduced. Throughout the study region, a low background PP value $\left(35 \mathrm{gC} \mathrm{m}^{-2}\right.$ year $\left.^{-1}\right)$ is used and the processes related to the ice margin in the MIZ are represented by additional local PP input in the northern part $\left(50 \mathrm{gC} \mathrm{m}^{-2}\right.$ year $\left.^{-1}\right)$ giving a total PP of $85 \mathrm{gC} \mathrm{m}^{-2}$ year $^{-1}$ in this region. This PP input reproduces a calibration data set in the study region (see [40] for details). This PP is total PP and is shown in Fig. 7. The input of terrestrial and residual organic carbon is directly controlled by the presence of the MIZ and the proximity to the coast line.

The constants used in Eq. 1 and in the equations in OFMod 3D are empirical. Most of the various equations describing carbon flux and primary productivity that exist were fitted to data using global datasets (see $[13,28]$ and references therein for details). With shallower water $(<200 \mathrm{~m})$ these relationships become more uncertain [35] and for specific environments carbon flux and burial efficiency may have to be adjusted [13]. OF-Mod 3D takes decreased preservation in shallow water into account by reducing the carbon flux (per default carbon flux in water shallower than $75 \mathrm{~m}$ is a fraction of 0.15 of deep water carbon flux). Here OF-Mod 3D was used with these default carbon flux (CF) settings in the study region and the model was able to reproduce the TOC and MOC distributions in the Barents Sea well (Fig. 6 in Pathirana et al. [40] and Fig. 5 of this paper). 


\section{SINMOD set-up}

One 3D ocean model that has been widely used for "topdown" modelling of PP in the Barents Sea and Arctic Ocean and to predict future scenarios is the coupled hydrodynamic-ice-chemical-ecosystem model SINMOD (e.g. $[60,71,72])$. SINMOD is a nested model with an outer grid of $20 \mathrm{~km}$ and an inner grid of $4 \mathrm{~km}$ resolution. Details about the setup of this particular model can be found in Wassmann et al. [71] and references therein. For this study, SINMOD was run for the year 2003 and GPP and export production at $50 \mathrm{~m}$ water depth for our study region was extracted.

\section{Core chronologies}

We have both $\mathrm{AMS}^{14} \mathrm{C}$-dated cores and radiogenic isotope dated cores available (Table 1). Sedimentation rates show large differences between these two methods. To compare PP variability, we apply only $\mathrm{AMS}^{14} \mathrm{C}$-dated cores, since the sedimentation conditions are better represented by $\mathrm{AMS}^{14} \mathrm{C}$ estimates than ${ }^{210} \mathrm{~Pb}$ for the last 6000 years BP: sedimentation rates calculated from $\mathrm{AMS}^{14} \mathrm{C}$ dates are very similar to those determined from sediment thickness maps of the Holocene sediments in the Barents Sea [40]. Sedimentation rates are calculated assuming constant sedimentation rates between consecutive $\mathrm{AMS}^{14} \mathrm{C}$-dated horizons. Sample ages are given in calibrated (kilo) ages before present (cal (k)yr BP; present $=1950 \mathrm{AD}[65]$.

\section{Results}

\section{Bulk organic properties}

Figure 2 shows the organic carbon content (TOC), $(\mathrm{C} / \mathrm{N})_{\text {org }}$ ratio (TOC vs. $\mathrm{N}_{\text {org }}$ ) and $\delta^{13} \mathrm{C}_{\text {org }}$ profiles versus depth. TOC content in all cores varies between 0.2 and $2.6 \mathrm{wt} \%$. With respect to TOC, there is limited downcore variability with depth in the cores. The cores R87 and BASICC1 with the lowest TOC contents of all cores show a gradual decrease from the top to the bottom which likely reflects remineralization during burial [17]. Along the open ocean core transect (R87, BASICC1, St20, BASICC8), TOC content increases from south to north. The $(\mathrm{C} / \mathrm{N})_{\text {org }}$ ratios vary between 6.9 and 23.9. There is a clear south-north divide while downcore variability is low. The southern cores (R1, R87, BASICC1) and St20 have low values $(<10)$ which suggests a high proportion of marine material in these cores (e.g. [53]). The northern cores (St1245, BASICC8 and JM10) have much higher $(\mathrm{C} / \mathrm{N})_{\text {org }}$ values suggesting more terrigenous material. $\delta^{13} \mathrm{C}_{\mathrm{org}}$ varies between -25.5 and
$-21.8 \%$ and the values also show a division between the southern and northern cores. The southern cores (R1, R87, BASICC1, St20, PSh-5159N) have values around $-22.5 \%$ suggesting mainly marine material, whereas the northern cores have values below $-24 \%$ indicative of more terrigenous material. Downcore variability is low in most cores except for a trend towards heavier values towards the top of the cores.

\section{Mixing model}

Figure 3 shows the regressions used to obtain the endmembers of the mixing model to determine the organic carbon fractions for the data set using values from Knies and Martinez [29] and Pathirana et al. [40]. The regressions of $\delta^{13} \mathrm{C}_{\text {org }}$ versus $\mathrm{N}_{\text {org }} / \mathrm{TOC}$ and $\% \mathrm{~N}_{\text {org }}$ and $\delta^{13} \mathrm{C}_{\text {org }}$ of Knies and Martinez [29] and Pathirana et al. [40] are supplemented with down-core data from the cores in this study, so that temporal variations are included. The new regression reveals a close correspondence of the previous and current terrestrial $(-26.1 \%)$ and marine $(-20.7 \%$ ) endmembers. This implies minimal variations with time and gives confidence for using the endmembers from the current data set on all cores.

\section{Organic carbon composition and distribution}

Figure 4 shows the marine (MOC) and terrestrial (TOM) organic fractions as functions of depth calculated with the two-endmember mixing model described above. JM10 has a higher TOM content in the lower part of the core (1-2 m core depth) compared to the top 0-1 m, whereas MOC content varies little throughout the core. St20, located at the edge of the MIZ and under the PF has the highest MOC content. The fjord cores St1245 and R1 also have high MOC content likely due to high accumulation rates and high flux of organic carbon generally found in fjords (e.g. $[21,62])$. Lowest MOC content is found in both the ice covered regions (core BASICC8) and the open ocean (core R87). In contrast, TOM increases from south to north in the Barents Sea with highest TOM in the ice-covered (BASICC8) and fjord cores (St1245, JM10), intermediate TOM in the MIZ (St20) to lowest values in the open ocean (R87).

Figure 5 shows the OF-Mod 3D simulated marine fraction compared to MOC in the top of the cores and the surface samples. Modelled MOC is low in the AW region south of the maximum ice extent and higher in the northern part of the study region. MOC is higher in ice-influenced regions and highest south of Spitsbergenbanken, in Hopen Deep, and Storfjord Trough. Overall simulated MOC and samples are of similar order of magnitude and the model is able to reproduce the MOC content in the surface samples. 

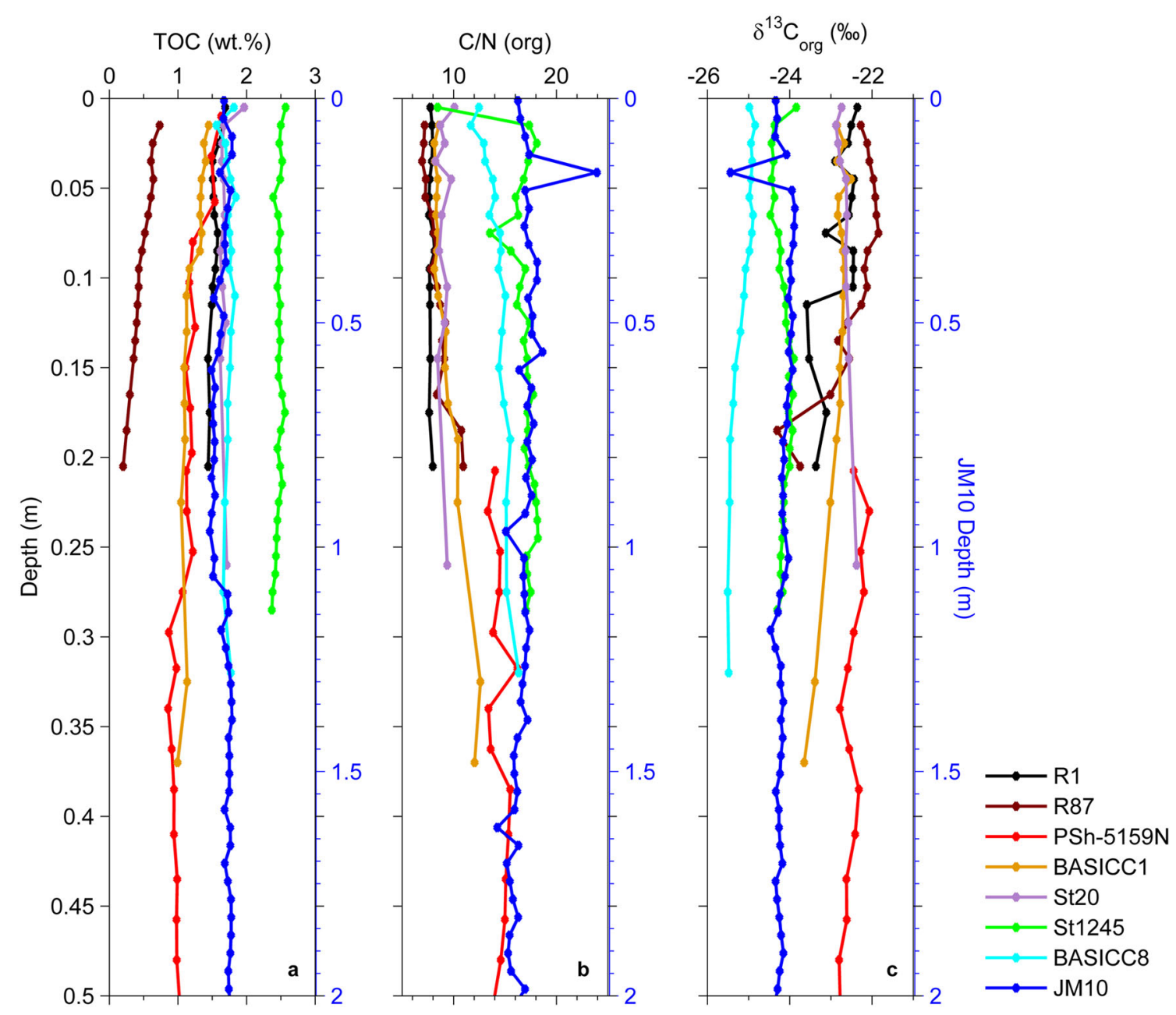

Fig. 2 a TOC, b organic C/N ratio (TOC/ $\mathrm{N}_{\text {org }}$ ) and $\mathbf{c} \delta^{13} \mathrm{C}_{\text {org }}$ for the 8 cores plotted against depth. Note that JM10 is plotted on its own axis. Note the south-to-north increasing trend in TOC for the open ocean cores

There are only very few larger deviations between the simulated values and the samples: in the north-eastern study region east of Svalbard (BASICC8), in Hopen Deep, and in the MIZ along the shelf break. BASICC8 has the most severe ice-cover and shortest growing season in the study region, explaining the low MOC content found in the sediment core. Model resolution $(5000 \mathrm{~m} \times 5000 \mathrm{~m})$ likely leads to mismatches between specific point values and simulation results: OF-Mod 3D uses a combination of water depth, distance to shore, and grain size to constrain the calculated values. If the topography changes rapidly, the values for the calculations in a grid cell may not be the same as the values for the core location; such a mismatch may well have led to an overall higher MOC content at this location. Similarly the low MOC zone to the east of Hopen Deep may extend further west, which may not be captured in OF-Mod in this detail. Along the shelf break, the grain size model may not be accurate enough to reproduce all variations over short distances.
Overall OF-Mod 3D simulates the MOC content in the samples well. Analogous to the evaluation of the model set-up in Pathirana et al. [40], a comparison of residuals (absolute difference between the model and the measurements) and the samples (Fig. 6) shows a low $R^{2}$ of 0.015 indicating no systematic trends or biases. This demonstrates that our model is well-suited to reconstruct the organic carbon content in the study region (see [40], for further details on the model performance). This instills confidence in the calculated regional PP distribution and implies that the simulated PP trends are suitable for the study region.

\section{Primary productivity reconstruction}

Figure 7 shows the reconstructed paleoproductivity (PP) rates and terrigenous organic matter (TOM) content in all AMS ${ }^{14} \mathrm{C}$-dated cores over the past 6000 years BP. The southern cores are situated in open water north of Norway, 


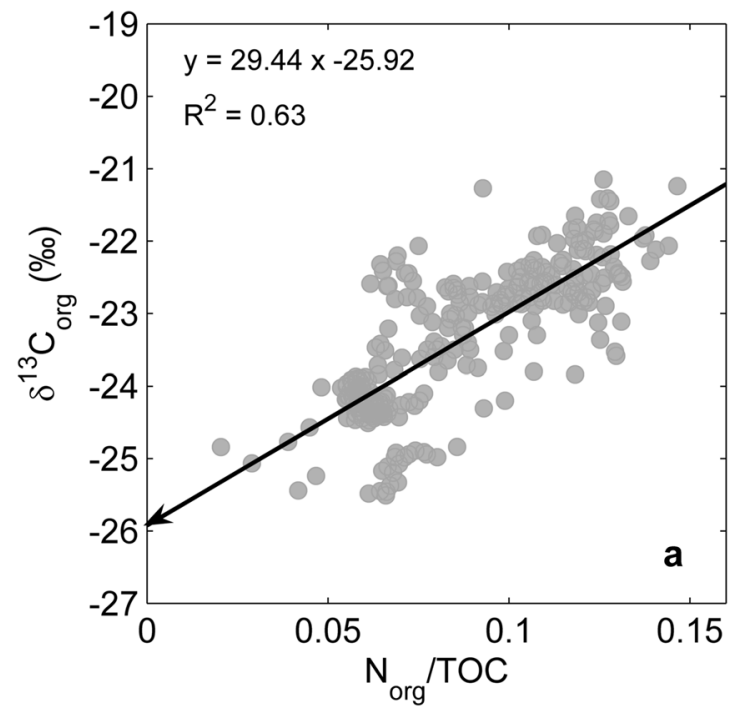

Fig. 3 Regressions for the endmember mixing model using the extended data set including surface samples from Knies and Martinez [29], and Pathirana et al. [40], and core data from this study.

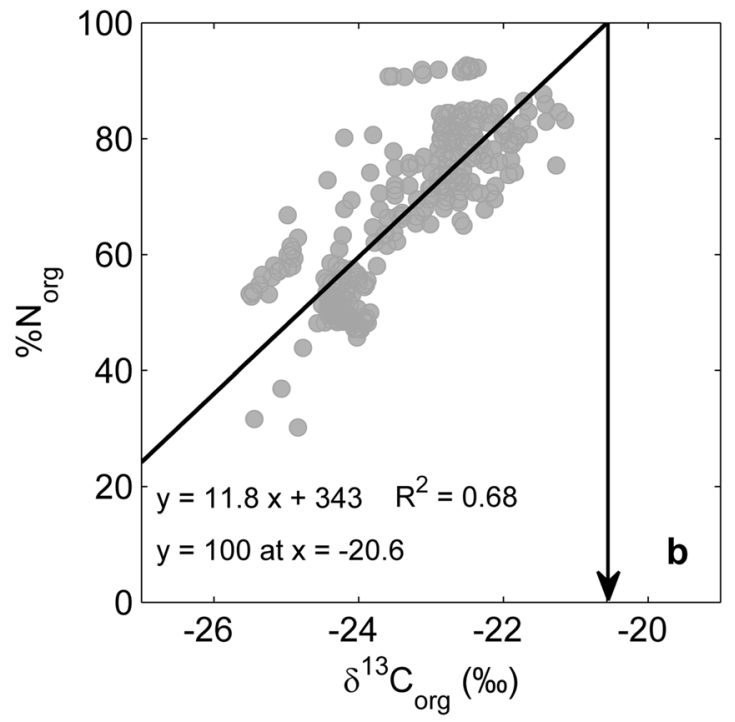

a determination of terrestrial endmember (arrowhead), b determination of marine endmember (arrowhead)
Fig. 4 Marine organic carbon (MOC) and terrestrial organic matter (TOM) content calculated with the endmember mixing model for the cores, plotted against depth. Note that JM10 is plotted on its own axis. There is limited downcore variability. Note the south-tonorth increasing trend in TOM content for the open ocean cores (R87, PSh-5159N, BASICC1, St20, BASICC8). The fjord cores (R1, St1245, JM10) show more variability
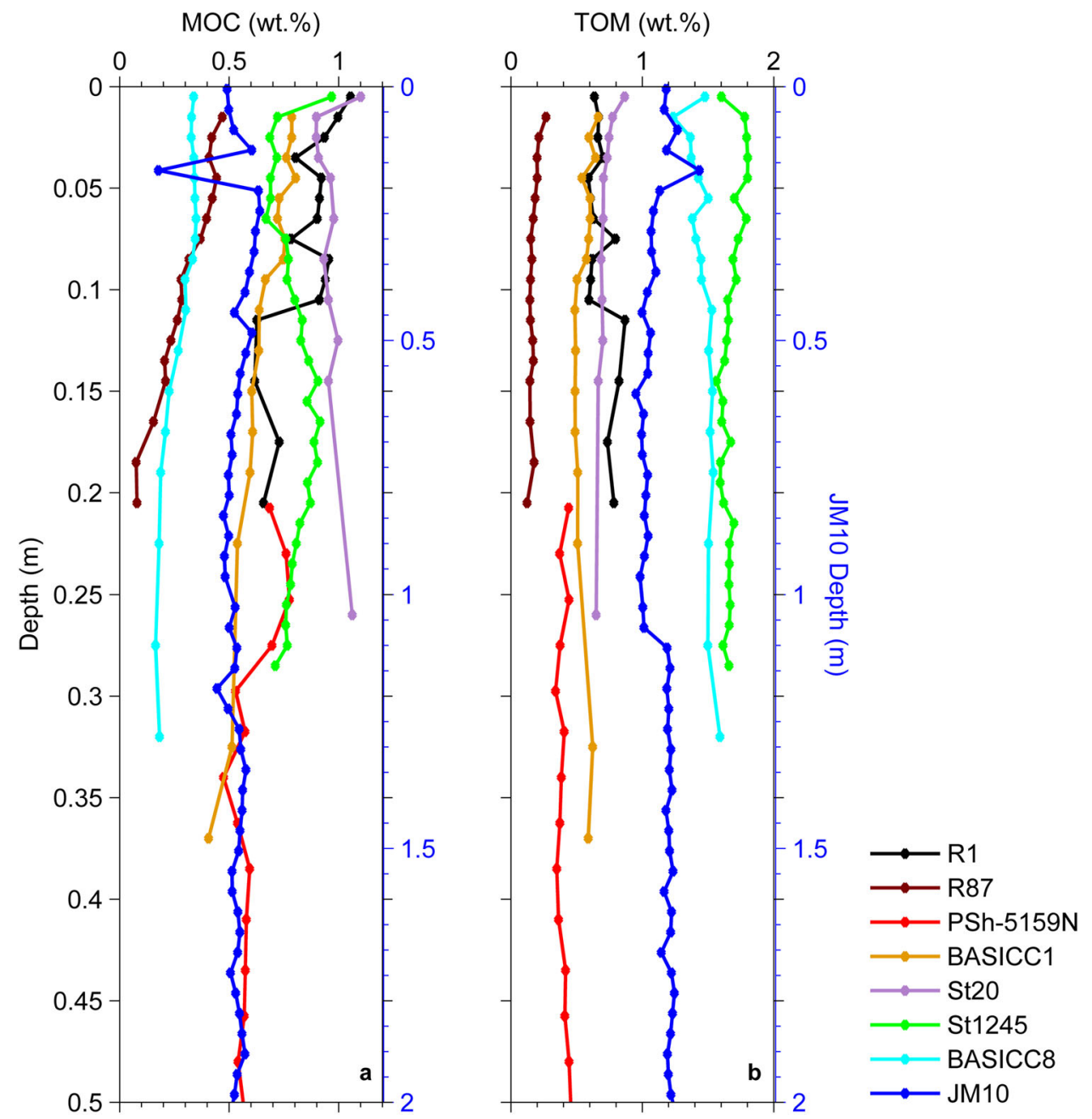
Fig. 5 Marine fraction modeled using OF-Mod 3D compared to core-top and surface sample MOC. Areas with water depth $<50 \mathrm{~m}$

(Spitsbergenbanken) are indicated by the grid of vertical white lines. The simulated and calculated MOC values are of similar order of magnitude and show that the model is wellcalibrated to reconstruct the organic carbon content in this area. Note that there are no core-top data for PSh-5159N. Note the low MOC content in the southern part of the model region and highest values south of Spitsbergenbanken, in Hopen Deep and in Storfjord Trough

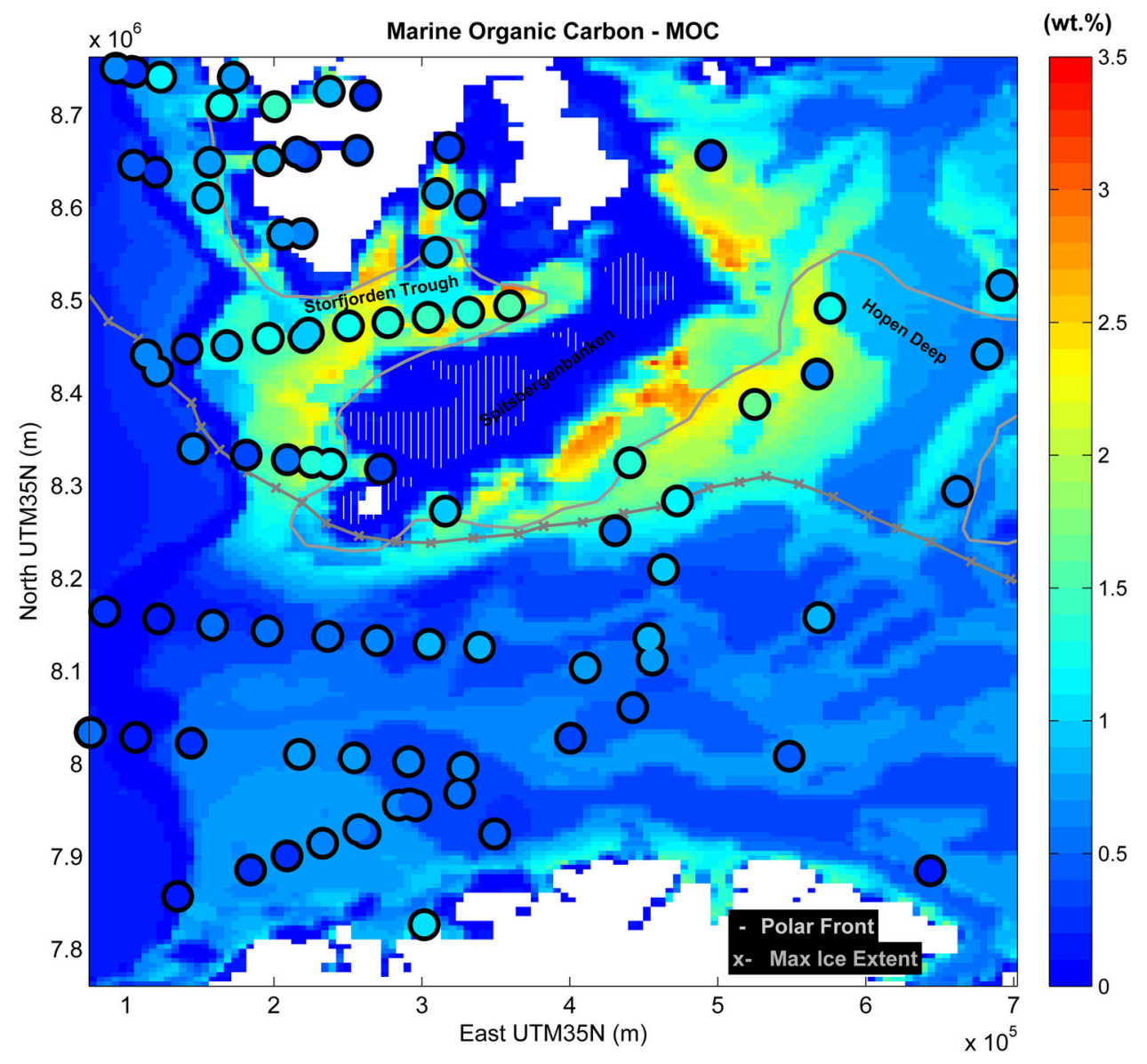

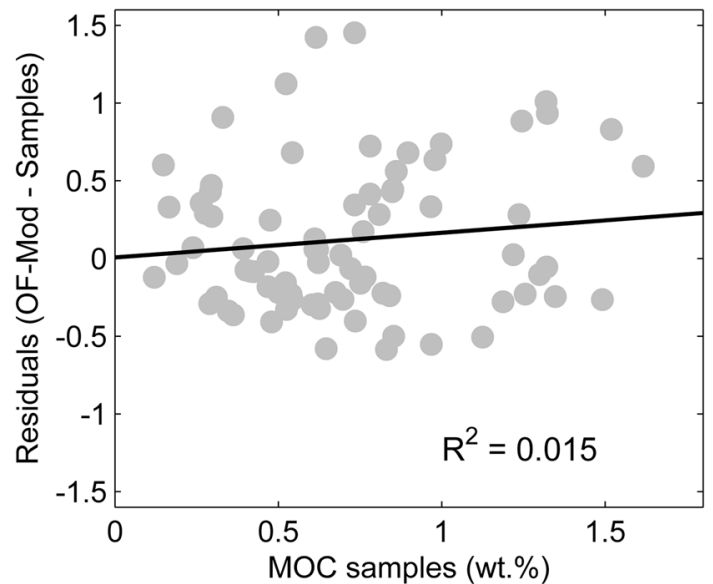

Fig. 6 Model performance evaluation using a regression of the residuals (absolute difference between the model and sample data) and the samples. The low regression coefficient indicates that there is no systematic bias in the model

well south of the maximum ice extent in an area that is entirely AW influenced under the modern circulation regime (Fig. 1). Two cores from southern Spitsbergen
(St1245, JM10) and the MIZ (St20) show PP variability over the last ca. 800 years. The open ocean cores (R87, PSh-5159N) have the lowest calculated PP. In cores R87 and PSh-5159N, PP changes little downcore. The northern cores JM10 and St1245 have maximum values in the middle part of the core and a decrease towards the top.

Figure 8 shows the primary productivity input in the OF-Mod 3D model with which the organic carbon content of the surface samples is reproduced. This PP distribution will from here on be referred to as the OF-Mod PP. The OF-Mod PP is low $\left(<40 \mathrm{gC} \mathrm{m}^{-2}\right.$ year $\left.^{-1}\right)$ in the southern $\mathrm{AW}$ region south of the maximum ice extent and high in the ice-influenced northern part of the model region. The highest PP (up to $100 \mathrm{gC} \mathrm{m}^{-2}$ year $^{-1}$ ) is used in the MIZ, especially above Spitsbergenbanken and the coastal areas around the south of Svalbard. The reconstructed PP in the core-tops (circles in Fig. 8), are of the same order of magnitude as the OF-Mod PP input and the model and core data agree well.

Figure 9a shows simulated gross primary production (GPP) in the surface waters for the year 2003 using SINMOD. Similar to many SINMOD predictions already 
Fig. 7 a PP and b TOM plotted against age for the AMS ${ }^{14} \mathrm{C}$ dated cores for the past 6000 years BP. Note the south (R87, PSh-5159N) to north (St20, JM10, St1245) trend in increasing PP and TOM and the higher PP variability in the northern, Arctic Water influenced cores

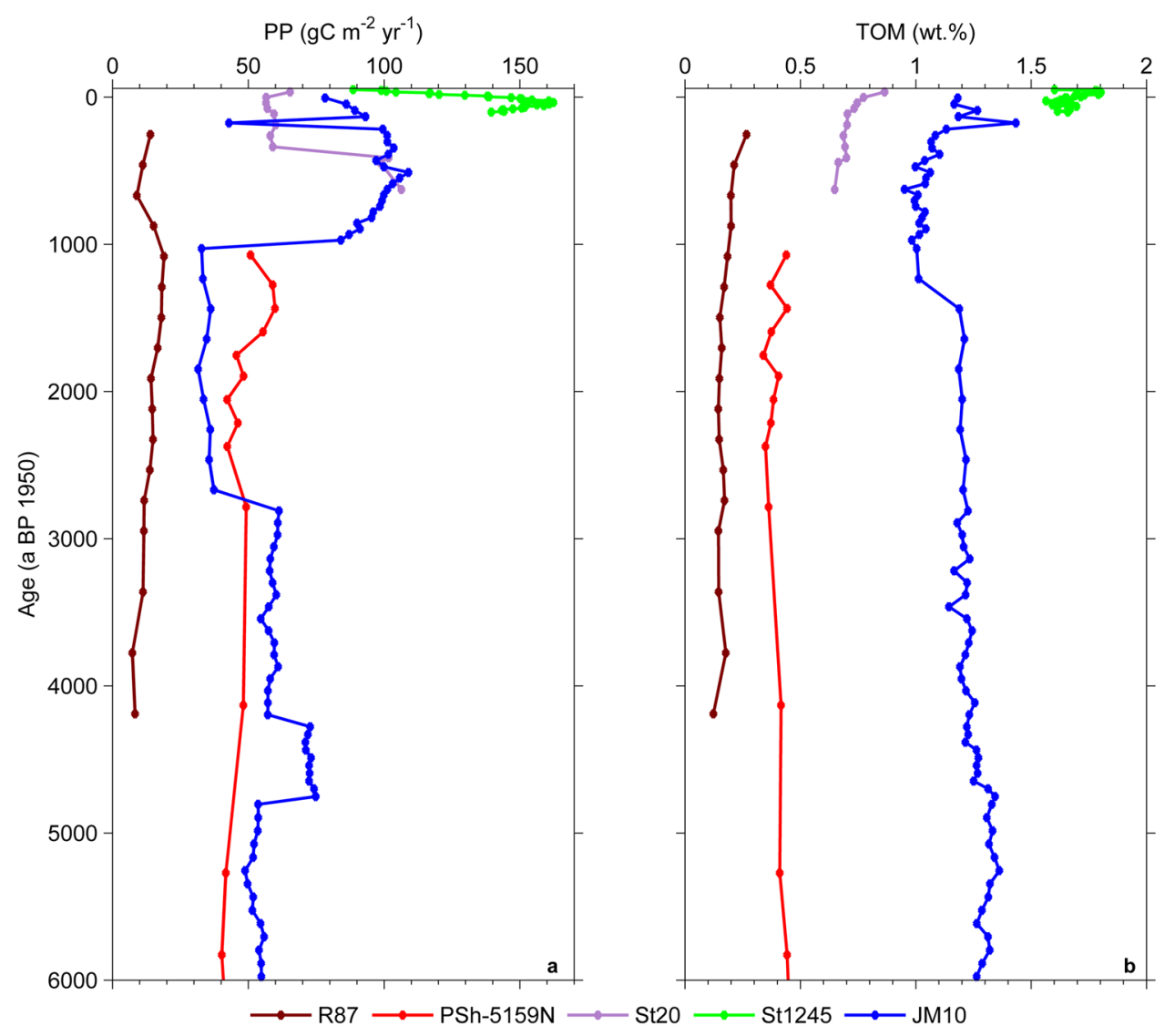

published $[11,71,72]$, the highest GPP $\left(>100 \mathrm{gC} \mathrm{m}^{-2}\right)$ is shown to occur in the AW region south of the maximum ice extent and along the shelf break, intermediate GPP in the MIZ region (80-100 $\mathrm{gC} \mathrm{m}^{-2}$ ) and lowest GPP in the ArW region of the Barents Sea $\left(<80 \mathrm{gC} \mathrm{m}^{-2}\right)$. Low GPP is also shown for Storfjorden. This is the opposite of our reconstructed PP (both from cores and with OF-Mod 3D) which has highest PP in the MIZ and lowest in the AW region of our model region (Fig. 8, OF-Mod PP).

Figure $9 \mathrm{~b}$ shows export production at $50 \mathrm{~m}$ water depth in our study region predicted from SINMOD. This depth was chosen because the highest vertical flux attenuation tends to occur at the pycnocline in 30-50 m water depth during peak bloom episodes [46]. Therefore export below this depth should represent true export to depth and organic matter potentially available for burial. In the western Barents Sea, the lowest SINMOD-modeled export (0-10 $\mathrm{gC} \mathrm{m}^{-2}$ ) occurs in the seasonally ice-covered northeastern ArW region and slightly higher export (10-30 $\mathrm{gC} \mathrm{m}^{-2}$ ) in the ice-free $\mathrm{AW}$ region. The highest simulated export $\left(>30 \mathrm{gC} \mathrm{m}^{-2}\right)$ occurs in the MIZ region south and north of Spitsbergenbanken, and off the southern tip of Svalbard. This pattern is more similar to our OF-Mod PP than surface water GPP (Fig. 8, OF-Mod PP).

\section{Discussion}

\section{Modelling of primary productivity and export production in the Barents Sea}

The correspondence of our OF-Mod PP with the SINMOD calculated export production rather than SINMOD GPP in the study region in order of magnitude and distribution is interesting and questions about potential reasons arise. Apart from modelling differences in time and space scales, resolution, and parameterization and approximation issues, specific water column processes in the upper $50 \mathrm{~m}$ (advection, stronger regenerated production, etc.) may be stronger than parameterized in the sedimentary models. The difference between the OF-Mod PP and the surface water GPP may be a suggestion that locally in the shallow Barents Sea environment with low sedimentation rates and strong current regime, the carbon flux equation used might need to be changed.

Comparing GPP and export production in the water column in Fig. 9a, b indicates that the SW Barents Sea is a highly productive region but retains a large portion of the biomass in the ecosystem and export to depth is low (30-40 $\mathrm{gC} \mathrm{m}^{-2}$ on average in the study region). These 
Fig. 8 Simulated marine productivity compared to coretop PP. Areas with water depth $<50 \mathrm{~m}$

(Spitsbergenbanken) are indicated by the grid of vertical black lines. Note that there are no core-top data for PSh-5159N. The simulated values agree well with the reconstructed PP values from the sediment cores. Note the low PP in the Atlantic Water region south of the maximum ice extent and the highest PP in the marginal ice zone and around the southern coast of Svalbard

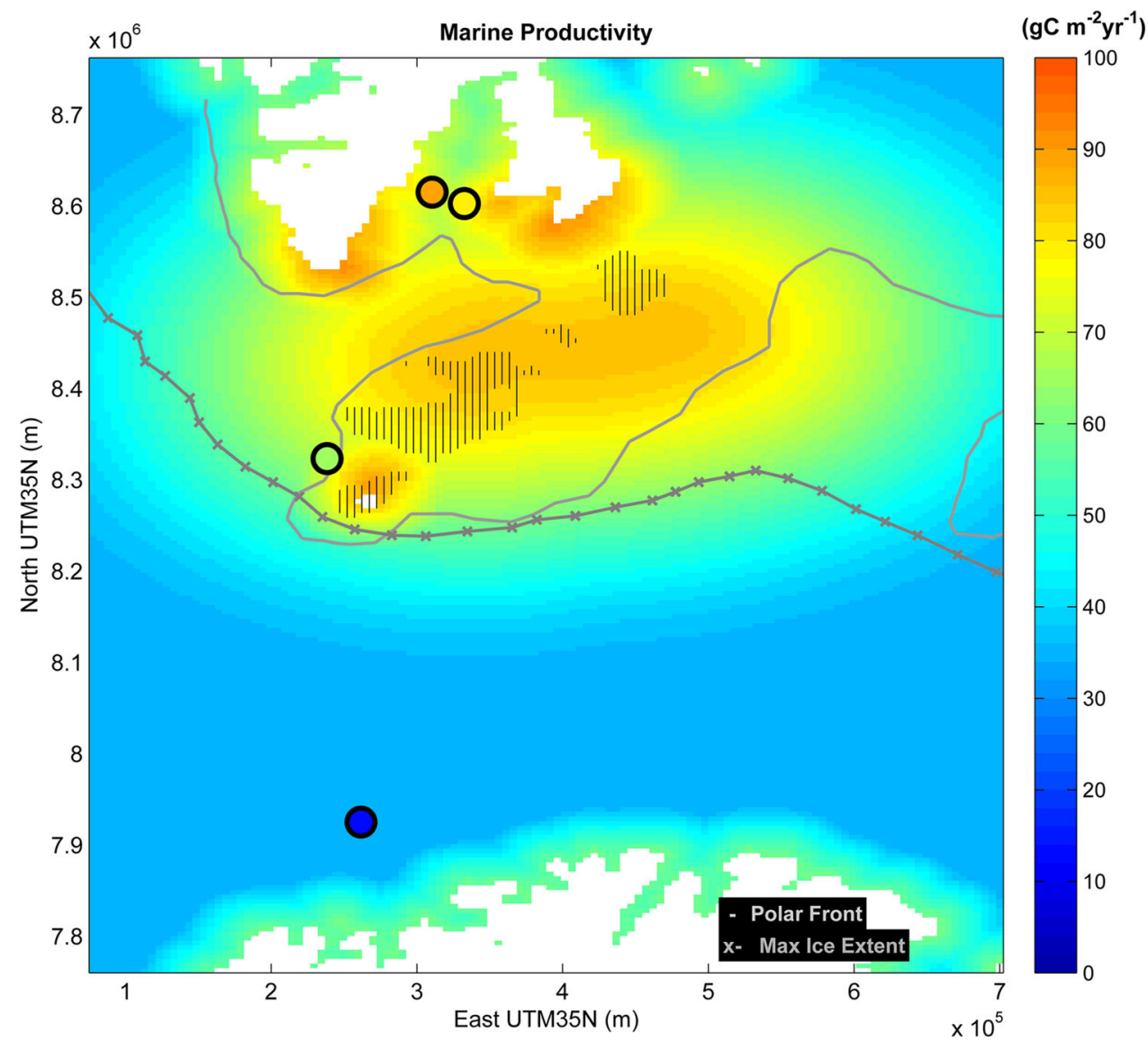

$\left(\mathrm{gC} \mathrm{m}^{-2} \mathrm{yr}^{-1}\right)$

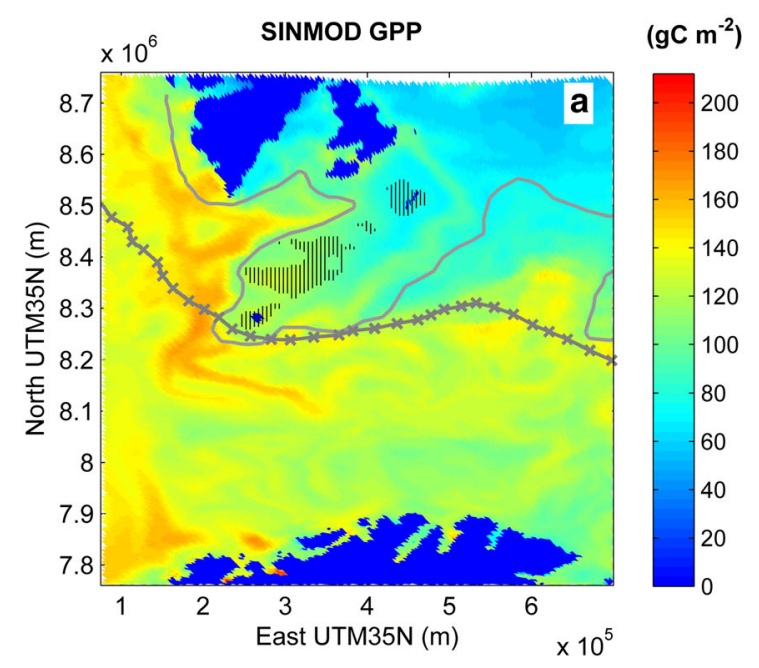

Fig. 9 a Gross primary production (GPP) and $\mathbf{b}$ export production at $50 \mathrm{~m}$ water depth as modeled by SINMOD for the year 2003 for our model region. Water depth $<50 \mathrm{~m}$ (Spitsbergenbanken) is indicated by the grid of black (white) vertical lines. Also shown are the location of the Polar Front and the maximum ice extent. Note the high GPP in

results corroborate findings by Reigstad et al. [46], who, using sediment traps, estimated that only $34 \%$ of PP is exported to depth and reaches the benthos in the southern

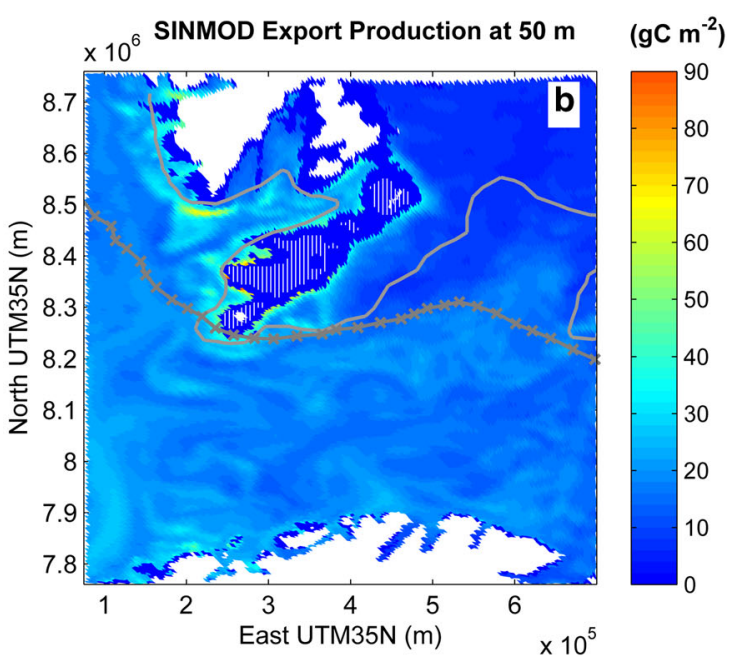

the Atlantic Water region and lower GPP in the ice-influenced and Arctic Water regions. Export production is highest north of Spitsbergenbanken in the MIZ, low in the Atlantic Water region and lowest in the Arctic Water region

Barents Sea, compared to $47 \%$ in the northern Barents Sea. This is also the pattern that is reflected in our MOC distribution (Fig. 5) and PP reconstruction (Fig. 8) with 
higher marine accumulation and higher reconstructed PP in the northern than the southern Barents Sea. The higher MOC content in the MIZ and ice-covered region (Fig. 5) may be a result of a combination of higher production and the addition of ice algae and TOM and thus more efficient export [39, 40, 66]. These results confirm that the export ratio is higher $(34 \%)$ in the ArW region due to a shorter productive season than in the AW sector [46]. Our results also support the notion that the AW region has higher overall annual production but also more retention and recycling in the water column and possibly usage by benthos (e.g. [6, 47, 70]). Therefore little organic matter is buried in the sediments [40] and as a consequence, lower PP is reconstructed using sediment data and used with the OF-Mod 3D approach (Fig. 8). In the MIZ, our data confirm the notion of high production in surface waters, together with more export and thus higher preservation of marine organic matter during peak bloom times. In addition transport to the flanks of Spitsbergenbanken and into the deeper channels and basins flushes the benthic systems with organic matter [75] and therefore more is buried in sediments and thus higher PP reconstructed using sedimentary organic carbon data. In addition, PP used as input for OF-Mod 3D in most of the model region is on the order of $40-50 \mathrm{gC} \mathrm{m}^{-2}$ year $^{-1}$ (Fig. 8), which is similar to the estimated carbon requirement for benthic populations in the Barents Sea at $\sim 40 \mathrm{gC} \mathrm{m}^{-2}$ year $^{-1}[46,70]$.

The combination of high PP with large amounts of both marine and terrestrial organic carbon and inorganic sediment suggests an effective transport system of organic carbon to the seafloor where it is available for burial (Figs. 8, 9b). Our results suggest that a combination of first-year ice and higher PP in a warming Arctic may point to a potential Arctic carbon sink.

On the other hand, the SW Barents Sea characterized by warm, saline AW can be seen as an example of a yearround ice-free Arctic Ocean. The SW Barents Sea develops a winter mixed layer, and phytoplankton blooms related to insolation and stratification occur in the spring [50] with generally high GPP overall. However, without any additional sediment input, no effective export mechanism for organic carbon to the seafloor seems to exists (Fig. 9b) and little organic matter is buried here (Fig. 5 this study, also Fig. 11 in [40]). An ice-free future Arctic may have higher primary production compared to today but without the effective export pump of the first-year ice, may not act as an effective carbon sink.

\section{Paleoproductivity changes over the last 6000 years}

In the following we discuss the results over the last 6000 years BP in three time steps: (1) the middle Holocene
(6000-2800 years BP), (2) the Early Late Holocene (2800-1000 years BP) and (3) the last 1000 years BP.

\section{Period I: 6000-2800 cal yr BP (Middle Holocene)}

In the southern Barents Sea, in the AW region, core R87 has lower MOC and TOM content and lower PP than PSh$5159 \mathrm{~N}$ (5 and $50 \mathrm{gC} \mathrm{m}^{-2}$ year $^{-1}$ for R87 and PSh-5159N, respectively). Both cores have little downcore variability. One likely explanation for the difference in PP is given by the different water depths between the two sites, $240 \mathrm{~m}$ for R87 and $422 \mathrm{~m}$ for PSh-5159N, and thus variable carbon flux, sedimentation rates and eventually PP rates. In addition, influence of sea ice, local or transported, may also contribute to the differences between the core sites. The observation of ice-rafted debris in sediments of core PSh$5159 \mathrm{~N}$ [48] indicates that transported sea ice reached this site occasionally. However, whether the melting of sea ice stimulated high PP rates in core PSh-5159N compared to R87 remains speculative and needs further investigation.

$\mathrm{PP}$ rates in the northern Barents Sea are somewhat higher and more variable (50-70 $\mathrm{gC} \mathrm{m}^{-2} \mathrm{year}^{-1}$ ) compared to the studied locations in the south (Fig. 7). This trend is also present in the content of TOM, which is significantly higher in the north compared to the south. These spatial differences in PP are similar to OF-Mod simulations under present day conditions [40]. Under present day conditions the variable MIZ is the main controlling factor for both in situ production and export of marine organic matter as well as release of TOM in the northern Barents Sea [29]. Reconstructions of the sea ice margin in the broader study region for this time period [38, 74], show a gradual southward expansion and increased influence of ArW in the Barents Sea (e.g. [16]). The latter suggests the presence of sea ice in the northern Barents Sea during the middle Holocene. This gradual cooling trend is observed all over the Nordic seas including the Barents Sea [1, 16, $23,61,74]$. One reason for the increasing sea ice coverage during the middle Holocene might be the coupling between decreasing summer irradiance at high northern latitudes [30] and amplifying positive feedbacks such as the complete flooding of the Arctic shelves and established modern sea-ice production/export in the Arctic Ocean [3, 74].

In contrast, lower TOM content in cores from the southern Barents Sea suggests the absence or only marginal influence of sea ice coverage in the southern Barents Sea. Hald et al. [16] reported a strong surface water temperature gradient of $12{ }^{\circ} \mathrm{C}$ between the northern and southern Barents Sea at around 5000 years BP. The wide range of production rates $\left(5-50 \mathrm{gC} \mathrm{m}^{-2}\right.$ year $\left.^{-1}\right)$ indicates a dynamic, variable environment as a result of sharp gradients between cold ArW and warm AW inflow. Highly variable sedimentation rates and strong bottom currents 
affect the particle settling and organic carbon preservation, resulting in variable estimates of PP rates and TOM supply. Still, the estimated PP (Fig. 8) between 6000 and 2800 years BP resembles modeled export production under present-day conditions (Fig. 9b) confirming a largely icefree depositional environment during this time period. The latter supports findings of Risebrobakken et al. [48] who suggested that the polar front retreated gradually to its present-day position by 7500 years BP.

\section{Period II: 2800-1000 cal yr BP (Early late Holocene)}

The decrease from moderately high and stable PP rates $\left(\sim 50 \mathrm{gC} \mathrm{m}^{-2}\right.$ year $\left.^{-1}\right)$ to significantly lower values $\left(\sim 35 \mathrm{gC} \mathrm{m}^{-2}\right.$ year $\left.^{-1}\right)$ in the northern Barents Sea characterizes the onset of the Early late Holocene at 2800 year BP (Fig. 7), although TOM supply remains largely unchanged (Fig. 7). In contrast, PP rates and TOM supply remain largely stable in the south with, however, a slight increase towards the end of the period. The decline in PP rates in the north occurs in the same time interval as radiogenic isotopes and sea-ice derived biomarkers suggest reduced inflow of waters from the Nordic seas and a southeastward shift of the MIZ in the study region [38, 73]. Maximum multiyear and landfast sea ice is reconstructed off the coast of northern Greenland since 2500 years BP and is linked to an increase in ice export from the western Arctic [14]. High sea ice abundances in the Nordic Seas are coeval with limited deep water convection in the Greenland Sea and a weaker Atlantic meridional overturning circulation (e.g. [67]). We interpret the decline in PP rates as a result of more dense, permanent sea ice coverage and less seasonality (melting/freezing) in the northern Barents Sea. This is potentially related to more severe winter conditions with more fast ice in Storfjorden, less particle flux to the seafloor, and less production during the growing season. It corroborates findings of increased proportions of agglutinated benthic foraminifera in Storfjorden during the same interval [43, 44], supporting inferences of colder and more severe environmental conditions in the northern Barents Sea. The reduction of TOM supply after 1300 years BP indicates less sediment entrainment and release along the MIZ due to more severe sea ice coverage at that time.

The southern Barents Sea seems not to be affected by the expansive sea ice extent. Similar PP rates (5 and $50 \mathrm{gC} \mathrm{m}^{-2}$ year $^{-1}$ at $\mathrm{R} 87$ and PSh-5159N respectively) and low TOM supply as reported during the middle Holocene suggest ice-free, present-day-like oceanographic conditions with only marginal influence of sea ice related processes [48]. This inference is supported by a sea surface temperature reconstruction from the western Barents Sea margin indicating the absence of sea ice between 3000 and 1600 years BP [52]. Furthermore, it fits well with the continuous presence of the subpolar planktic foraminifer species Turborotalita quinqueloba off western Svalbard during the past 3000 years BP [74] suggesting persistent influence of Atlantic-derived water masses along the western Barents Sea margin and consequently limited southward extension of the MIZ. However, PP rates in PSh-5159N and R87 show a slight increase towards the end of the time period, between 1900 and 1500 years BP. Risebrobakken et al. [48] found evidence for low salinity episodes in the surface water during 2200-1900 and 1500-1000 years BP and inferred that these represent increased coastal water and thus seasonal sea ice influence during colder conditions in the SW Barents Sea. Core R87 also shows some evidence of these periods. Whether these periods of seasonal sea ice stimulated phytoplankton growth and enhanced export production remains uncertain and requires further investigation.

\section{Period III: 1000-0 cal yr BP (late Holocene-present)}

The increase from lower PP rates $\left(\sim 30 \mathrm{gC} \mathrm{m}^{-2}\right.$ year $\left.^{-1}\right)$ to significantly higher values ( $\sim 90$ to $>150 \mathrm{gC} \mathrm{m}^{-2}$ year $^{-1}$ ) in the northern Barents Sea characterizes the onset of the late Holocene at 1000 year BP (Fig. 7). PP values remain high at the northernmost sites (Storfjorden), but with a pronounced decline towards the present day. Along the MIZ (St.20), high PP rates decrease at about 500 years BP and remain largely stable with a slight increase towards the present day (Fig. 7). During this time, TOM supply increases gradually towards the present day (Fig. 7). In contrast, PP rates and TOM supply remain constantly low $\left(<20 \mathrm{~m}^{-2}\right.$ year $\left.^{-1}\right)$ where available in the SW Barents Sea (Fig. 7).

The increase in PP rates in the north at about 1000 years BP corroborates an overall trend of increased influence of Atlantic-derived water masses in western Barents Sea surface waters $[10,52]$. Particularly at nearby MIZ location St.20, sustained AW inflow has influenced surface water conditions from ca. 1000 years BP [10]. This contrasts conditions further north, off the western Svalbard coast, where sea ice remained largely predominant in surface waters until the last century [38, 63, 73, 74]. The persistent influence of AW at the MIZ from ca. 1000 years BP may explain the rise in PP rates in Storfjorden as a consequence of a highly fluctuating sea ice boundary with strong seasonal gradients compared to the Early late Holocene (2800-1000 years BP). Frequent episodes of sediment entrainment and release during sea ice freezing and melting processes may have stimulated phytoplankton growth and potentially increased the export towards the seabed during the last 1000 years BP. The repeated shifts of warmer and colder conditions due to variable influence of AW/ArW in Storfjorden [43, 44] and along the western Svalbard margin 
$[73,74]$ are not recorded in our northernmost PP record. A likely reason for this observation could be the formation of coastal polynyas, which have been frequently observed in Storfjorden during the last decade $[15,58]$. The episodic melting/freezing of sea ice in the polynya seems to allow for constant high production rates (Fig. 7) and high organic carbon burial [76] with seemingly little influence of cold/ warm spells during the last 1000 years. In contrast, the drop at MIZ location St20 around 500 years BP may be the result of the climate deterioration during the Medieval Climate Anomaly (MCA)/Little Ice Age (LIA) transition. The overall cooling during the LIA may have caused a prolonged phase of sea ice coverage at the modern MIZ and thus a reduced window of phytoplankton growth. Indeed, Macias Fauria et al. [34] showed that during the last 800 years the largest sea ice extent in the western Nordic Seas occurred during the LIA. Additionally, a recent reconstruction of late summer Arctic sea ice extent shows large sea ice extent at the beginning of the LIA [26]. Along the western Svalbard and Barents Sea margin, Müller et al. [38] and Berben et al. [4] provided evidence for frequently fluctuating sea ice conditions during the last 1000 years BP similar to those of the present day. Nonetheless, more expansive sea ice coverage and cooling of the subsurface water masses in this region is inferred for the LIA from different micropaleontological studies $[5,10$, 74] supporting our observation of a temporarily reduced window for phytoplankton blooms and thus reduced export production to the seabed.

The prominent decline in production rates in our northernmost location (St1245) has previously been explained by a reduced annual duration of the MIZ in the area due to global warming [76]. Interestingly, a parallel site (JM10) shows a similar pattern with a gradual PP decline towards the present day. We argue that reduced production along with reduced export towards the seabed during recent times is an indication for less frequent episodes of sediment entrainment/release and thus for less sea ice freezing/melting processes in a warming climate.

\section{Conclusion}

In this study we focus on late Holocene primary productivity variability in the western Barents Sea and its response to variable sea ice coverage combining primary productivity (PP) reconstructed from sediment core data and locally inferred temporal trends with regional PP trends used as input for simulations with a well-constrained organic facies model (OF-Mod 3D).

Marine organic carbon (MOC) simulated with OF-Mod 3D and core-top values are of similar order of magnitude and show that OF-Mod 3D performs well in reconstructing the organic carbon content in the Barents Sea sediments. The highest PP (up to $100 \mathrm{gC} \mathrm{m}^{-2}$ year $^{-1}$ ) used in OFMod 3D to obtain a good fit between modelled and measured values is in the marginal ice zone (MIZ), especially above Spitsbergenbanken and the coastal areas around the south of Svalbard and lowest PP in the SW AW sector. Core-top PP reconstructed from sediment data is of the same order of magnitude as the model and the model and core data agree well.

This distribution is different than the distribution of surface water primary productivity simulated with a 3D ocean model (SINMOD), where the highest gross primary productivity (GPP) is shown to occur in the surface waters in the AW sector south of the maximum ice extent and along the shelf break and lowest GPP in the Arw region of the Barents Sea. On the other hand, SINMOD-predicted export production at $50 \mathrm{~m}$ water depth is more similar to our reconstructed PP than surface water GPP.

Reconstructed PP rates from sediment cores in the northern Barents Sea are more variable during the last 6000 years and are generally higher than in the ice-free south where they remain largely stable throughout the middle to late Holocene. This regional variation fits well with the input of TOM, which is significantly higher in the north compared to the south. This suggests the presence of sea ice in the northern Barents Sea during the middle Holocene.

PP rates in the SW Barents Sea resemble modelled export production under present conditions throughout the last 6000 years and confirm a largely ice-free depositional environment and conditions which are similar to modern conditions for most of the time period. A slight increase in MOC and PP in the SW Barents Sea cores towards modern times indicates a strengthening of the AW inflow in the SW Barents Sea over the last 6000 years and a possible increase in surface water production and export of marine organic carbon to depth.

Our results suggest that a combination of first-year ice and higher PP in a warming Arctic may point to a potential Arctic carbon sink while sea ice is still present. On the other hand, an ice-free future Arctic may have higher primary production compared to today. But without the effective export pump of the first-year ice, it may not act as an effective carbon sink any more.

Acknowledgments This work is a contribution to the CASE Initial Training Network funded by the European Community's 7th Framework Programme FP7 2007/2013, Marie-Curie Actions, under Grant Agreement No. 238111. Additionally, this work was partly supported by the Research Council of Norway through its Centres of Excellence funding scheme, project number 223259. The authors also wish to thank the MAREANO programme (www.mareano.no) for allowing the generous use of sediment and core data for this project. All MAREANO partners and cruise participants are thanked for their contributions. We thank the editor Henning Bauch and two 
anonymous reviewers for their helpful and constructive comments which greatly improved this manuscript.

Open Access This article is distributed under the terms of the Creative Commons Attribution 4.0 International License (http://crea tivecommons.org/licenses/by/4.0/), which permits unrestricted use, distribution, and reproduction in any medium, provided you give appropriate credit to the original author(s) and the source, provide a link to the Creative Commons license, and indicate if changes were made.

\section{References}

1. Andrews JT, Belt ST, Olafsdottir S, Masse G, Vare LL (2009) Sea ice and marine climate variability for NW Iceland/Denmark Strait over the last $2000 \mathrm{cal}$. year BP. Holocene 19:775-784. doi:10.1177/0959683609105302

2. Arrigo KR, van Dijken G, Pabi S (2008) Impact of a shrinking Arctic ice cover on marine primary production. Geophys Res Lett. doi:10.1029/2008g1035028

3. Bauch HA et al (2001) Chronology of the Holocene transgression at the North Siberian margin. Glob Planet Change 31:125-139

4. Berben SMP, Husum K, Cabedo-Sanz P, Belt ST (2014) Holocene sub-centennial evolution of Atlantic water inflow and sea ice distribution in the western Barents Sea. Clim Past 10:181-198. doi:10.5194/cp-10-181-2014

5. Bonnet S, De Vernal A, Hillaire-Marcel C, Radi T, Husum K (2010) Variability of sea-surface temperature and sea-ice cover in the Fram Strait over the last two millennia. Mar Micropaleontol 74:59-74

6. Cochrane SKJ, Denisenko SG, Renaud PE, Emblow CS, Ambrose WG, Ellingsen IH, Skarðhamar J (2009) Benthic macrofauna and productivity regimes in the Barents Sea-Ecological implications in a changing Arctic. J Sea Res 61:222-233. doi:10.1016/j.seares.2009.01.003

7. Comiso JC, Parkinson CL, Gersten R, Stock L (2008) Accelerated decline in the Arctic sea ice cover. Geophys Res Lett. doi:10. 1029/2007g1031972

8. Dalpadado P et al (2014) Productivity in the Barents Sea-response to recent climate variability. PLoS ONE 9:e95273. doi:10. 1371/journal.pone.0095273

9. Divine DV, Dick C (2007) March through August ice edge positions in the Nordic Seas, 1750-2002. Boulder, Colorado, USA

10. Dylmer CV, Giraudeau J, Eynaud F, Husum K, De Vernal A (2013) Northward advection of Atlantic water in the eastern Nordic Seas over the last 3000 year. Clim Past 9:1505-1518. doi:10.5194/cp-9-1505-2013

11. Ellingsen I, Dalpadado P, Slagstad D, Loeng H (2008) Impact of climatic change on the biological production in the Barents Sea. Clim Change 87:155-175. doi:10.1007/s10584-007-9369-6

12. Falk-Petersen $S$ et al (2000) Physical and ecological processes in the marginal ice zone of the northern Barents Sea during the summer melt period. J Mar Syst 27:131-159

13. Felix M (2014) A comparison of equations commonly used to calculate organic carbon content and marine palaeoproductivity from sediment data Marine Geology 347:1-11. doi:10.1016/j. margeo.2013.10.006

14. Funder S et al (2011) A 10,000-year record of Arctic Ocean seaice variability-view from the beach. Science 333:747-750. doi:10.1126/science. 1202760

15. Haarpaintner J (1999) The Storfjorden polynya: ERS-2 SAR observations and overview. Polar Res 18:175-182

16. Hald $M$ et al (2007) Variations in temperature and extent of Atlantic Water in the northern North Atlantic during the
Holocene. Quatern Sci Rev 26:3423-3440. doi:10.1016/j.quas cirev.2007.10.005

17. Hedges JI, Keil RG (1995) Sedimentary organic matter preservation: an assessment and speculative synthesis. Mar Chem 49:81-115

18. Henson S, Cole H, Beaulieu C, Yool A (2013) The impact of global warming on seasonality of ocean primary production. Biogeosciences 10:4357-4369. doi:10.5194/bg-10-4357-2013

19. Hill VJ, Matrai PA, Olson E, Suttles S, Steele M, Codispoti LA, Zimmerman RC (2013) Synthesis of integrated primary production in the Arctic Ocean: II. In situ and remotely sensed estimates. Prog Oceanogr 110:107-125. doi:10.1016/j.pocean. 2012.11.005

20. Holdal H, Kristiansen S (2008) The importance of small-celled phytoplankton in spring blooms at the marginal ice zone in the northern Barents Sea. Deep Sea Res II 55:1-2185. doi:10.1016/j. dsr2.2008.05.012

21. Howe JA (2010) Fjord systems and archives. Geological Society of London, London

22. Hunt GL, Stabeno P, Walters G, Sinclair E, Brodeur RD, Napp JM, Bond NA (2002) Climate change and control of the southeastern Bering Sea pelagic ecosystem. Deep Sea Res II 49:5821-5853

23. Jennings AE, Knudsen KL, Hald M, Hansen CV, Andrews JT (2002) A mid-Holocene shift in Arctic sea-ice variability on the East Greenland Shelf. Holocene 12:49-58. doi:10.1191/ 0959683602hl519rp

24. Jensen H, Knies J, Finne TE, Thorsnes T (2007) Mareano 2006miljøgeokjemiske resultater fra Tromsøflaket, Ingøy-djupet, Lopphavet og Sørøysundet. Geological Survey of Norway, Trondheim

25. Jensen H, Knies J, Finne TE, Thorsnes T (2008) Mareano 2007miljøgeokjemiske resultater fra Troms II og Troms III. Geological Survey of Norway, Trondheim

26. Kinnard C, Zdanowicz CM, Fisher DA, Isaksson E, De Vernal A, Thompson LG (2011) Reconstructed changes in Arctic sea ice over the past 1450 years. Nature 479:509-512

27. Knies J, Brookes S, Schubert CJ (2007) Re-assessing the nitrogen signal in continental margin sediments: new insights from the high northern latitudes. Earth and Planetary Science Letters 253:471-484. doi:10.1016/j.eps1.2006.11.008

28. Knies J, Mann U (2002) Depositional environment and source rock potential of Miocene strata from the central Fram Strait: introduction of a new computing tool for simulating organic facies variations. Mar Pet Geol 19:811-828

29. Knies J, Martinez P (2009) Organic matter sedimentation in the western Barents Sea region: terrestrial and marine contribution based on isotopic composition and organic nitrogen content. Norw J Geol 89:79-89

30. Laskar J, Robutel P, Joutel F, Gastineau M, Correia ACM, Levrard B (2004) A long-term numerical solution for the insolation quantities of the Earth. Astron Astrophys 428:261-285. doi:10.1051/0004-6361:20041335

31. Leu E, Søreide JE, Hessen DO, Falk-Petersen S, Berge J (2011) Consequences of changing sea-ice cover for primary and secondary producers in the European Arctic shelf seas: timing, quantity, and quality. Prog Oceanogr 90:18-32. doi:10.1016/j. pocean.2011.02.004

32. Loeng H (1991) Features of the physical oceanographic conditions of the Barents Sea. Polar Res 10:5-18

33. Luchetta A, Lipizer M, Socal G (2000) Temporal evolution of primary production in the central Barents Sea. J Mar Syst 27:177-193

34. Macias Fauria M et al (2010) Unprecedented low twentieth century winter sea ice extent in the Western Nordic Seas since A.D. 1200. Clim Dyn 34:781-795. doi:10.1007/s00382-0090610-Z 
35. Mann U, Zweigel J (2008) Modelling source-rock distribution and quality variations: the organic facies modelling approach. Spec Publ Int Assoc Sedimentol 40:239-274

36. Matrai PA, Olson E, Suttles S, Hill V, Codispoti LA, Light B, Steele M (2013) Synthesis of primary production in the Arctic Ocean: I. Surface waters, 1954-2007. Prog Oceanogr 110:93-106. doi:10.1016/j.pocean.2012.11.004

37. Michel C, Ingram RG, Harris LR (2006) Variability in oceanographic and ecological processes in the Canadian Arctic Archipelago Progress. Oceanography 71:379-401

38. Müller J, Werner K, Stein R, Fahl K, Moros M, Jansen E (2012) Holocene cooling culminates in sea ice oscillations in Fram Strait. Quatern Sci Rev 47:1-14. doi:10.1016/j.quascirev.2012. 04.024

39. Navarro-Rodriguez A, Belt ST, Knies J, Brown TA (2013) Mapping recent sea ice conditions in the Barents Sea using the proxy biomarker IP25: implications for palaeo sea ice reconstructions Quaternary. Sci Rev. doi:10.1016/j.quascirev.2012.11. 025

40. Pathirana I, Knies J, Felix M, Mann U (2014) Towards an improved organic carbon budget for the western Barents Sea shelf. Clim Past 10:569-587. doi:10.5194/cp-10-569-2014

41. Perovich DK, Light B, Eicken H, Jones KF, Runciman K, Nghiem SV (2007) Increasing solar heating of the Arctic Ocean and adjecent seas, 1979-2005: attribution and role in the icealbedo feedback. Geophys Res Lett. doi:10.1029/2007/ GL031480

42. Post E et al (2013) Ecological consequences of sea-ice decline. Science 341:519-524. doi:10.1126/science. 1235225

43. Rasmussen TL, Thomsen E (2014) Brine formation in relation to climate changes and ice retreat during the last 15,000 years in Storfjorden, Svalbard, $76-78^{\circ} \mathrm{N}$. Paleoceanography 29:911-929. doi:10.1002/2014pa002643

44. Rasmussen TL, Thomsen E (2015) Palaeoceanographic development in Storfjorden, Svalbard, during the deglaciation and Holocene: evidence from benthic foraminiferal records. Boreas 44:24-44. doi:10.1111/bor.12098

45. Reigstad M, Carroll J, Slagstad D, Ellingsen I, Wassmann P (2011) Intra-regional comparison of productivity, carbon flux and ecosystem composition within the northern Barents Sea. Prog Oceanogr 90:33-46. doi:10.1016/j.pocean.2011.02.005

46. Reigstad M, Wexels Riser C, Wassmann P, Ratkova T (2008) Vertical export of particulate organic carbon: attenuation, composition and loss rates in the northern Barents Sea. Deep Sea Res II 55:2308-2319. doi:10.1016/j.dsr2.2008.05.007

47. Renaud PE, Morata N, Carroll ML, Denisenko SG, Reigstad M (2008) Pelagic-benthic coupling in the western Barents Sea: processes and time scales. Deep Sea Res II 55:2372-2380. doi:10. 1016/j.dsr2.2008.05.017

48. Risebrobakken B, Moros M, Ivanova EV, Chistyakova N, Rosenberg R (2010) Climate and oceanographic variability in the SW Barents Sea during the Holocene. Holocene 20:609-621. doi:10.1177/0959683609356586

49. Sakshaug E (2004) Primary and secondary production in the Arctic Seas. In: Stein R, Macdonald RW (eds) The organic carbon cycle in the Arctic Ocean. Springer, Heidelberg, pp 63-81

50. Sakshaug E, Kovacs K (2009) Introduction. In: Sakshaug E, Johnsen G, Kovacs K (eds) Ecosystem Barents Sea. Tapir Academic Press, Trondheim, pp 9-32

51. Sakshaug E, Skjoldal HR (1989) Life at the ice edge Ambio 18:60-67

52. Sarnthein M, Kreveld SV, Erlenkeuser H, Grootes PM, Kucera M, Pflaumann U, Schulz M (2003) Centennial-to-millennial-scale periodicities of Holocene climate and sediment injections off the western Barents shelf, 75 N. Boreas 32:447-461. doi:10.1080/ 03009480310003351
53. Schubert CJ, Calvert SE (2001) Nitrogen and carbon isotopic composition of marine and terrestrial organic matter in Arctic Ocean sediments: implications for nutrient utilization and organic matter composition. Deep Sea Res I 48:789-810

54. Screen JA, Simmonds I (2010) The central role of diminishing sea ice in recent Arctic temperature amplification. Nature 464:1334-1337. doi:10.1038/nature09051

55. Serreze MC, Holland MM, Stroeve J (2007) Perspectives on the Arctic's shrinking sea-ice cover. Science 315:1533-1536. doi:10. 1126/science. 1139426

56. Serreze MC et al (2000) Observational evidence of recent change in the northern high-latitude environment. Clim Change 46:159-207. doi:10.1023/A:1005504031923

57. Silva JA, Bremner JM (1966) Determination and isotope-ratio analysis of different forms of nitrogen in soils: 5. Fixed ammonium. Soil Sci Soc Am J 30:587-594. doi:10.2136/sssaj1966. $03615995003000050017 \mathrm{x}$

58. Skogseth R, Smedsrud LH, Nilsen F, Fer I (2008) Observations of hydrography and downflow of brine-enriched shelf water in the Storfjorden polynya. Svalbard J Geophys Res. doi:10.1029/ $2007 \mathrm{jc} 004452$

59. Slagstad D, Ellingsen IH, Wassmann P (2011) Evaluating primary and secondary production in an Arctic Ocean void of summer sea ice: an experimental simulation approach Progress. Oceanography 90:117-131. doi:10.1016/j.pocean.2011.02.009

60. Slagstad D, McClimans $T$ (2005) Modeling the ecosystem dynamics of the Barents sea including the marginal ice zone: I. Physical and chemical oceanography. J Mar Syst 58:1-18. doi:10. 1016/j.jmarsys.2005.05.005

61. Ślubowska-Woldengen M, Koc N, Rasmussen TL, KlitgaardKristensen D, Hald M, Jennings AE (2008) Time-slice reconstructions of ocean circulation changes on the continental shelf in the Nordic and Barents Seas during the last 16,000 cal year B.P. Quatern Sci Rev 27:1476-1492

62. Smith RW, Bianchi TS, Allison M, Savage C, Galy V (2015) High rates of organic carbon burial in fjord sediments globally Nature Geosci 8:450-453. doi:10.1038/ngeo2421

63. Spielhagen RF et al (2011) Enhanced Modern Heat Transfer to the Arctic by Warm Atlantic Water. Science 331:450-453. doi:10.1126/science.1197397

64. Stein R, Macdonald RW (2004) The organic carbon cycle in the Arctic Ocean. Springer, Heidelberg

65. Stuiver M, Reimer PJ, Braziunas TF (1998) High-precision radiocarbon age calibration for terrestrial and marine samples. Radiocarbon 40:1127-1151

66. Tamelander T, Reigstad M, Hop H, Carroll ML, Wassmann P (2008) Pelagic and sympagic contribution of organic matter to zooplankton and vertical export in the Barents Sea marginal ice zone. Deep Sea Res II 55:2330-2339. doi:10.1016/j.dsr2.2008. 05.019

67. Telesiński MM, Spielhagen RF, Bauch HA (2014) Water mass evolution of the Greenland Sea since late glacial times. Clim Past 10:123-136. doi:10.5194/cp-10-123-2014

68. Vare LL, Masse G, Belt ST (2010) A biomarker-based reconstruction of sea ice conditions for the Barents Sea in recent centuries. Holocene 20:637-643. doi:10.1177/0959683609355179

69. Wassmann P (2011) Arctic marine ecosystems in an era of rapid climate change progress. Oceanography. doi:10.1016/j.pocean. 2011.02.002

70. Wassmann P et al (2006) Food webs and carbon flux in the Barents Sea Progress. Oceanography 71:232-287. doi:10.1016/j. pocean.2006.10.003

71. Wassmann P, Slagstad D, Ellingsen I (2010) Primary production and climatic variability in the European sector of the Arctic Ocean prior to 2007: preliminary results. Polar Biol 33:1641-1650. doi:10.1007/s00300-010-0839-3 
72. Wassmann P, Slagstad D, Riser C, Reigstad M (2006) Modelling the ecosystem dynamics of the Barents Sea including the marginal ice zone II. Carbon flux and interannual variability Journal of Marine Systems 59:1-24. doi:10.1016/j.jmarsys.2005.05.006

73. Werner K, Frank M, Teschner C, Müller J, Spielhagen RF (2014) Neoglacial change in deep water exchange and increase of sea-ice transport through eastern Fram Strait: evidence from radiogenic isotopes. Quatern Sci Rev 92:190-207. doi:10.1016/j.quascirev. 2013.06.015

74. Werner K, Spielhagen RF, Bauch D, Hass HC, Kandiano E (2013) Atlantic Water advection versus sea-ice advances in the eastern Fram Strait during the last 9 ka: multiproxy evidence for a two-phase Holocene. Paleoceanography 28:283-295. doi:10. 1002/palo.20028

75. Węsławski JM et al (2012) A huge biocatalytic filter in the centre of Barents Sea shelf? Oceanologia 54:325-335. doi:10.5697/oc. $54-2.325$

76. Winkelmann D, Knies J (2005) Recent distribution and accumulation of organic carbon on the continental margin west off Spitsbergen. Geochem Geophys Geosyst. doi:10.1029/2005gc000916 